\title{
Clusterizations, Mergers and Acquisitions of Higher Education in Indonesia
}

\author{
Rifda Arafah ${ }^{1, *}$, Muhammad Kristiawan ${ }^{2}$ and Sudarwan Danim ${ }^{2}$ \\ ${ }^{1}$ Islamic State Institute of Bengkulu, Indonesia \\ ${ }^{2}$ University of Bengkulu, Indonesia \\ *Corresponding author. Email: rfda.araff@iainbengkulu.ac.id
}

\begin{abstract}
Clusterizations, mergers, and acquisitions of university institutions are carried out to provide a framework for the development of development policies, the development of higher education, and to enable universities to enhance their competencies, their higher education standards, and also the quality of the effective implementation of the Tri Dharma of higher education. Clusterizations classify universities according to their level of growth so that they can act as a source of knowledge on the standard of higher education performance in Indonesia for the general public. In the meantime, acquisitions and mergers are carried out not only to reduce the number of universities but also to improve the competence and standards of higher education. The Indonesia higher education cluster classifies universities in Indonesia into five classes based on four main aspects, namely input, process, output, and outcome. There are three schemes for mergers and acquisitions: the merger of separate universities with the same base, the merger of universities with different foundations, and the merger of universities, large and small, with the same vision and mission. Meanwhile, the limited adequacy and suitability of lecturers after mergers and acquisitions, ownership of land and property after mergers and acquisitions, and a new undefined curriculum are the issues that obstruct the merger and acquisition stage of higher education. This hurdle makes universities unable to pursue the clustering method in the process of mergers and acquisitions. The recommendations for clusterizations are aimed at strengthening the capacity of higher education to develop an international reputation, strengthening internal resource management skills, promoting improved management systems, improving the quality of inputs and processes, and promoting understanding of the implementation of Tri Dharma. Then, for mergers and acquisitions, the government is required to take a strong stand in rationalizing the composition of lecturers and students, promoting the accreditation of study programs, monitoring transfers of leadership, planning criteria for the management of facilities and infrastructure, and respecting the rights and duties of lecturers and educational staff.
\end{abstract}

Keywords: Clusterizations, Mergers, Acquisitions, Higher education.

\section{INTRODUCTION}

The higher education sector worldwide has experienced phenomenal growth over the past few decades, and the standard of teaching and research has also increased. The truth is that for much of its funding and provision, higher education must depend on the private sector, however, until recently, market competition among higher education institutions has been severely restricted by the government. In an effort to expand the standard of teaching and study in higher education institutions, market-based policies must be used by the government [1]. In May 2005, the Korean government with the intent to reform both public and private universities, set out detailed strategies which can be summarized as follows:(1) enrolment cuts, and merger and acquisition policies; (2) specialization of the existing private higher educational institutions; (3) incorporation of the national universities; (4) forming new university-industry links for regional economic development; and (5) the liberation of the domestic education market [2].

Different things happen in India, pressed by budgetary constraints, the India's government appears to have decided on profit-oriented privatization of higher education as the solution. As India's highest regulatory body in the field of higher education, the Yash Pal Committee redefine the higher education by (1) creating 
a higher education vision as reflected in the curriculum structure, university benchmarks, international comparisons, and educational policies, including costs and pricing; (2) advising unions and state governments; (3) the establishment of criteria, procedures and systems for the admission, accreditation and exit of institutions and programs; (4) the creation of funding sources and mechanisms; (5) the promotion of efficient and open governance; (6) the establishment of a national higher education database; (7) the promotion of an atmosphere for attracting talented young people to education and research; (8) developing mechanisms to enrich the learning and discovery environment by softer contact between students and teachers; (9) finding ways to progressively liberate universities from the administrative burden of associated colleges; and (10) reporting annually on the state of higher education to Parliament [3].

Higher education in Indonesia is regulated by Law of the Republic of Indonesia Number 12 of 2012 and on article 4 states that higher education has the role of developing capacities and shaping with integrity the character and civilization of the country in the light of the growth of the nation's intellectual life; through the implementation of the Tri Dharma, to develop innovative, sensitive, creative, trained, competitive and cooperative academics and to develop science and technology by paying attention to and applying humanities values [4].

Furthermore, it is mentioned in Article 7 that the minister is responsible for higher education administration. Regulation, preparation, oversight, supervision, and assessment as well as coaching and communication are included in this responsibility.On the relation to article 56, all these responsibilities are carried out based on data relating to the implementation of higher education for all university institutions, nationally incorporated into Higher Education Database, established and controlled by the ministry or managed by an institution designated by the ministry.

Various policies related to higher education have been implemented based on the evidence provided by the Higher Education Database. The government of Indonesia has introduced clusterization, mergers, and acquisitions of university institutions in order to boost the quality of higher educationand to be first type of corporate university which is a developed, mainstream, non-profit university that responds to economic and technological pressures by adopting modern for-profit corporations' management practices [5].

Based on national data, Indonesia currently has a very large number of university institutions, with a total of 4.621 institutions, consisting of 633 universities, 238 institutes, 909 academies, 36 community colleges, 304 polytechnic, and dominated by 2.501 schools of higher learning [6]. It is feared that the number of university institutions that are too large andstill do not match their full output will not be able to promote improvement in the standard of Indonesian education, but rather to increase the workload of the Ministry of Education and Culture in higher education coaching and supervision [7].

Article 15 of Regulation No 100 of 2016 of the Minister of Science, Technology and Higher Education of the Republic of Indonesia notes that changes to private university institutions can consist of: (1) changing the name and/or location of private universities; (2) changing the type of private universities; (3) move from the old organizing agency to the new organizing agency of the management of private universities; (4) merger of twoor more private universities into new private universities, (5) acquisition of one or more private universities into oneother private university, and (6) split of oneprivate university into twoor more private universities.

Reducing 1000 private universities is one of the national goals set by the Ministry of Science, Technology and Higher Education by the end of 2019 . Asking private colleges to merge immediately is one way of doing this. This is to boost the reputation of private colleges and their quality. There are two forms of restructuring, namely mutual mergers and acquisitions, which can be introduced. Some of the benefits of the merger process of private university education are that private universities are becoming healthier, more financially powerful. In addition, universities also have better management.

\section{RESULTS AND DISCUSSION}

\subsection{Clusterizations}

Clusterization is the effort of the Indonesian government under the guidance of the Ministry of Education and Culture to chart the performance of Indonesian academic universities. This clustering is not a ranking but, according to their level of growth, a grouping of universities. The key objective of the cluster is to provide a framework for the development of development policies, the development of higher education, and the promotion of the quality of the implementation of the Tri Dharma of Higher Education by universities in a sustainable way. In addition, higher education clusters serve to provide information on the standard of higher education performance in Indonesia to the general public.

Variable importance information from Indonesian university institutions was again defined in 2020 on the basis of four main aspects, including the quality of human and student capital (input), the management of higher education institutions (process), the short-term performance of universities (output) and the 
achievement of long-term higher education performance (outcome). However, there are some changes andadditions to the indicators representing each of the main components. Of course, with the hope that these main components will better reflect the status of the Indonesian University Institutions and also in line with the coverage of each main components.

The indicators used to assess the performance of higher education in the input aspect include the percentage of doctoral degree lecturers, the percentage of head and professorship lecturers, the ratio of the number of lecturers to the number of students, the number of students from abroad, and the number of lecturers employed as industry practitioners for at least 6 months. There are 9 indicators used in the process, including institutional accreditation, research program accreditation, online learning, collaboration with higher education, completeness of PDDIKTI reports, number of study programs in collaboration with DUDI, NGOs, or QS Top 100 WCU by subject, number of study programs implementing Freedom to Learn programs, and number of students taking the Freedom to Learn programs by subject. Four indicators are used in the output aspect, including the number of indexed scientific papers per lecturer, the performance of studies, the performance of students, and the number of study programs that have earned international accreditation or certification. Meanwhile, there are five indicators used in the outcome aspect, including innovation performance, number of citations per lecturer, number of patents per lecturer, the performance of community service, and the percentage of college graduates who get a job within 6 months [8].

Clustering of higher education is organized and designed for both individual university education performance data and overall higher education performance in the sense of quality improvement. Accordingly, data sources for clustering use legitimate and ready-to-use data with the following characteristics: (1) data that can be used directly, that is, data regularly reported to PDDIKTI;(2) data on the outcomes of performance evaluations of higher education carried out by work units within the Directorate-General for Higher Education but not presented in PDDIKTI; (3) data not covered by PDDIKTI but organized, obtained by work units and highly important for clustering; (4) data from outside PDDIKTI that is reasonably well known and readable.

The clustering score for each measurementin each aspect is based on the achievements of the higher education institutions. The overall college success score is weighted by each measure. This stage is very significant and can be used as a control tool for policies for the development of higher education. The indicator's weight is calculated by taking three things into account, such as meaning, the measurement validity, and comparability. Importance is the effect of the indicator in the creation of a higher education institution quality, while the measurement validity relates to the validity of the measurements carried out, including the quality of the data and the ease of verification and comparability is calculated when all forms, status, and categories of university institutions are covered by the indicator.

There is no dichotomy between publicuniversities and private universities in this grouping. In evaluation terms, there is no distinction between public and private universities. Leadership and synergy still remains the core. As long as the higher education chancellor can create synergies, this is the university's strength to realize its vision and goal to enhance the quality of the entire academic community. The results of the clustering of higher education in 2020 are expected to inspire Indonesian universities to continue to make continuous improvements in quality through smart work, excitement, and cooperation between universities. Also, university institutions are required, in compliance with the mandate of Law Number 12 of 2012 about Higher Education, to periodically and regularly update data and report on the progress of production achievements through the Higher Education Database or PDDIKTI [9].

The total number of universities in the 2020 cluster consists of 2.136 universities based on data from participating university institutions in PDDIKTI. Then, after evaluating the results of the 2020 higher education cluster, five higher education clusters were obtained, comprising 15 universities in cluster 1, 34 universities in cluster 2, 97 universities in cluster 3, 400 universities in cluster 4 , and cluster 5 of 1.590 universities.

The following tables describe the average clustering results, the features of each cluster, the clustering follow-up recommendations, and a list of universities in the $1^{\text {st }}$ and $2^{\text {nd }}$ clusters.

Table 1.Clustering average 2020 results(Education, http://lidikti6.id, 2020)

\begin{tabular}{|c|c|c|c|c|c|}
\hline Cluster & $\begin{array}{c}\text { College } \\
\text { Number }\end{array}$ & $\begin{array}{c}\text { Average } \\
\text { Input }\end{array}$ & $\begin{array}{c}\text { Average } \\
\text { Process }\end{array}$ & $\begin{array}{c}\text { Average } \\
\text { Output }\end{array}$ & $\begin{array}{c}\text { Average } \\
\text { Outcome }\end{array}$ \\
\hline $\mathbf{1}$ & 15 & 3,480 & 3,476 & 2,968 & 2,720 \\
\hline $\mathbf{2}$ & 34 & 2,628 & 3,243 & 1,523 & 1,677 \\
\hline $\mathbf{3}$ & 97 & 1,976 & 2,872 & 0,963 & 1,168 \\
\hline $\mathbf{4}$ & 400 & 1,381 & 2,449 & 0,470 & 0,665 \\
\hline $\mathbf{5}$ & 1.590 & 0,780 & 1,480 & 0,087 & 0,092 \\
\hline Total & 2.136 & 0,995 & 1,767 & 0,241 & 0,292 \\
\hline
\end{tabular}

\subsection{Mergers}

The private university merger comprises several private universities, each run by 1 (one) organizing agency, and 1 (one) new private university run by 1 (one) new organizing agency. For instance, a private 
university (A) managed by Foundation A and a private university (B) managed by Foundation B are merged into a private university $(\mathrm{C})$ managed by Foundation $\mathrm{C}$.

Table 2. Features and follow-up recommendations of each cluster (Education, http://ldikti6.id, 2020)

\begin{tabular}{|c|c|c|}
\hline Cluster & Features & $\begin{array}{c}\text { Follow-up } \\
\text { Recommendations }\end{array}$ \\
\hline 1 & $\begin{array}{l}\text { - Strong human capital } \\
\text { and infrastructure are } \\
\text { used efficiently to } \\
\text { attain high national } \\
\text { achievements. } \\
\text { - Able to be upgraded } \\
\text { to global rankings }\end{array}$ & $\begin{array}{l}\text { Strengthened potential } \\
\text { for international } \\
\text { reputation building }\end{array}$ \\
\hline 2 & $\begin{array}{l}\text { - Human resources and } \\
\text { leadership are } \\
\text { generally good } \\
\text { - Failed to be used } \\
\text { sufficiently to achieve } \\
\text { high national } \\
\text { achievements }\end{array}$ & $\begin{array}{l}\text { Strengthening internal } \\
\text { management ability to } \\
\text { utilize higher education } \\
\text { resources }\end{array}$ \\
\hline 3 & $\begin{array}{l}\text { - Medium-quality } \\
\text { management and } \\
\text { human resources } \\
\text { - Not yet able to be } \\
\text { used to accomplish } \\
\text { national achievements }\end{array}$ & $\begin{array}{l}\text { - Improvement of } \\
\text { human resource } \\
\text { efficiency } \\
\text { - Strengthened internal } \\
\text { management capacity }\end{array}$ \\
\hline 4 & $\begin{array}{l}\text { - Low-quality human } \\
\text { resources and } \\
\text { management } \\
\text { - Did not present any } \\
\text { national achievements }\end{array}$ & $\begin{array}{l}\text { - Improved Human } \\
\text { Resources Quality } \\
\text { and management } \\
\text { framework } \\
\text { - Improved levels of } \\
\text { input and process } \\
\text { quality } \\
\text { - Increased awareness } \\
\text { of Tri Dharma } \\
\text { accomplishments }\end{array}$ \\
\hline 5 & $\begin{array}{l}\text { - The level of } \\
\text { management and } \\
\text { human resources is } \\
\text { very low } \\
\text { - No sign of } \\
\text { accomplishment }\end{array}$ & $\begin{array}{l}\text { - Improved human } \\
\text { resource quality and } \\
\text { internal management } \\
\text { (further analysis for } \\
\text { teaching staff) } \\
\text { - Enhanced levels of } \\
\text { input and process } \\
\text { standard } \\
\text { - Increased knowledge } \\
\text { of Tri Dharma } \\
\text { accomplishments }\end{array}$ \\
\hline
\end{tabular}

Table 3.List of universities in the $1^{\text {st }}$ and $2^{\text {nd }}$ clusters (Education, http://lldikti6.id, 2020)

\begin{tabular}{|c|c|c|}
\hline Rank & $\mathbf{1}^{\text {st }}$ clusters & $2^{\text {nd }}$ clusters \\
\hline $\mathbf{1}$ & InstitutPertanian Bogor & UniversitasPendidikan Indonesia \\
\hline $\mathbf{2}$ & Universitas Indonesia & Telkom University \\
\hline $\mathbf{3}$ & UniversitasGadjahMada & UniversitasNegeri Semarang \\
\hline
\end{tabular}

\begin{tabular}{|c|c|c|}
\hline 4 & UniversitasAirlangga & UniversitasNegeri Surabaya \\
\hline 5 & InstitutTeknologi Bandung & UniversitasNegeri Jakarta \\
\hline 6 & InstitutTeknologiSepuluhNopember & Universitas Kristen Petra \\
\hline 7 & UniversitasHasanuddin & UniversitasJember \\
\hline 8 & UniversitasBrawijaya & UniversitasUdayana \\
\hline 9 & UniversitasDiponegoro & UniversitasSyiah Kuala \\
\hline 10 & UniversitasPadjadjaran & Universitas Islam Indonesia \\
\hline 11 & UniversitasSebelasMaret & UniversitasBina Nusantara \\
\hline 12 & UniversitasNegeri Yogyakarta & UniversitasTrisakti \\
\hline 13 & UniversitasAndalas & Universitas Riau \\
\hline 14 & Universitas Sumatera Utara & Universitas Lampung \\
\hline 15 & UniversitasNegeri Malang & Universitas Surabaya \\
\hline 16 & & UniversitasTarumanegara \\
\hline 17 & & UniversitasKatholikParahyangan \\
\hline 18 & & UniversitasMercuBuana \\
\hline 19 & & UniversitasSriwijaya \\
\hline 20 & & $\begin{array}{c}\text { UniversitasMuhammadiyah } \\
\text { Yogyakarta }\end{array}$ \\
\hline 21 & & UniversitasNegeriMakasar \\
\hline 22 & & $\begin{array}{c}\text { UniversitasKatholik Indonesia } \\
\text { Atmajaya }\end{array}$ \\
\hline 23 & & UniversitasAtmajaya Yogyakarta \\
\hline 24 & & UniversitasNegeri Medan \\
\hline 25 & & Universitas Sam Ratulangi \\
\hline 26 & & UniversitasMataram \\
\hline 27 & & UniversitasPendidikanGanesha \\
\hline 28 & & UniversitasSanata Dharma \\
\hline 29 & & Universitas Islam Malang \\
\hline 30 & & UniversitasEsaUnggul \\
\hline 31 & & $\begin{array}{c}\text { UniversitasKatholikWidya } \\
\text { Mandala Surabaya }\end{array}$ \\
\hline 32 & & UniversitasLambungMangkurat \\
\hline 33 & & $\begin{array}{c}\text { UniversitasMuhammadiyah } \\
\text { Malang }\end{array}$ \\
\hline 34 & & UniversitasMerdeka Malang \\
\hline
\end{tabular}

The reasons for the merger of these private universities are: (1) the shared vision of several private universities is to increase the pace of the realization of the vision of a new private university by the merger of several private universities into 1 (one) new private university under the management of 1 (one) new foundation; (2) several private universities managed by each foundation no longer have the ability, both academically and non-academically, to incorporate their study programs, but this ability will grow and expand if 
under the management of a new foundation, several private universities are merged into 1 (one) new private university.

The merger of several private universities into one (one) new private university would result in the following: (1) the transfer of ownership of all properties (facilities, infrastructure, other assets) of several foundations whose private universities are merged must be in the name of the new foundation managing the newly merged private university; (2) the accreditation status of the study program; (3) the data and information in the higher education database (PD DIKTI) must be modified from data and information on several merged private universities to 1 (one) data and 1 (one) new merged private university information.

The following criteria apply the prerequisite for mergingprivate universities: (1) each foundation overseeing multiple private universities to be integrated is legitimate in its legal nature; (2) the combined study programs in private higher education institutions are restricted to studies that have at least a minimum accredited status and classification; (3) all private university institutions that are combined have reported the implementation of higher education to the Higher Education Database (PD DIKTI); (4) if a new private university institution requires the addition of a new study program, the curriculum defined for a new study program opened at a new private university is developed in line with the national standards of higher education competences of the graduates; (5) if new private university institutions require the addition of new study programs, there should be at least 6 (six) lecturers per study program unless otherwise stipulated by laws and regulations, with the lowest qualification having a master's degree in the field of science and technology by study programs that will be opened in the newly merged private university institutions; (6) if a new private university institution requires the addition of a new study program, the lecturers in the study program that will be opened at the merged private university institution are at most 58 (fifty-eight) years old when accepted as a lecturer, willing to work full time for 40 ( forty) hours per week, do not have a National Lecturer Identification Number (NIDN) or Special Lecturer Identification Number (NIDK), or if the lecturer already have a NIDN/NIDK from other study programs at the newly merged private university, must maintain the lecturer ratio and students in abandoned study programs, not teachers who already have the Educator and Education Personnel Serial Number (NUPTK), are not permanent employees of other agencies, and are not state civil servants;(7) if the addition of a new study program to a new private university facility, educational staff to be formed at the facilities of the merged private university, shall be employed by at least 3 (three) persons for each study program, or a person for the service of a consolidated library of new private university institutions, with a minimum diploma of three, maximum age 56 (fifty-six years), ready to work for 40 (for forty) hours per week in a full-time setting.

Requirements(1) and (5) are absolute conditions, meaning that the plan to combine private university institutions will still be assessed but not further processed if these two requirements are not complied with.

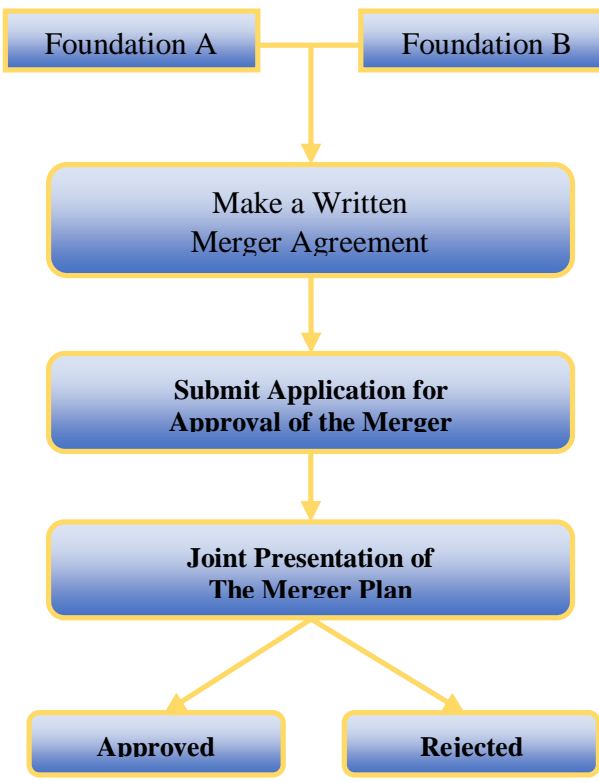

Figure 1. The first stage of merger procedures

Furthermore, the documents that must be submitted to meet the requirements for merging universities are made in the Portable Document Format(PDF) and must be uploaded to the silemkerma.ristekdikti.go.id website. Documentation for merging private university institutions shall be: (1) notary deed of establishment and amendments to each merging foundation; (2) a decree from the competent authority concerning the validation of each foundation merging as a legal entity; (3) notary law of merging several foundations into 1 (one) new foundation that will manage 1 (one) new private university merged; (4) a letter of a decision on the ratification of a new foundation arising from fusion as a legal entity from the competent authorities; (5) a letter of application for the merger into 1 (one) new private university from a new base several private university institutions; (6) MoEC, MoNE, or MoTRHE decree authorizing of each private university institution to merge with the state and requiring each research program to be opened up at each private university institution to be merged; (7) land certificate on behalf of the new fund or land rent arrangement between the new foundation and the status of the land titleholder by 21 December 2035 for proposed new private university institutions; (8) BAN-PT accreditation template for mergers filled in by the new foundation (where changes arise in the form of a private university); (9) where the 
addition of a new research program, the accreditation instrument to open a BAN-PT/LAM study program, completed by a new foundation per study program, was required by a new private university; (10) financial reports prepared for the last 2 years, according to laws and regulations on the merger of private universities by each foundation; and (11) higher educational recommendations (L2 DIKTI) for private higher learning institutions in newly-merged areas.

The first stage of the procedure for submitting private university institutions is described in Figure 1. Meanwhile, if the application for the merger of private university institutions to the Director General of the Institute for Science, Technology and Higher Education first stage is approved, then the procedure flow for stage II is described in the following flow:

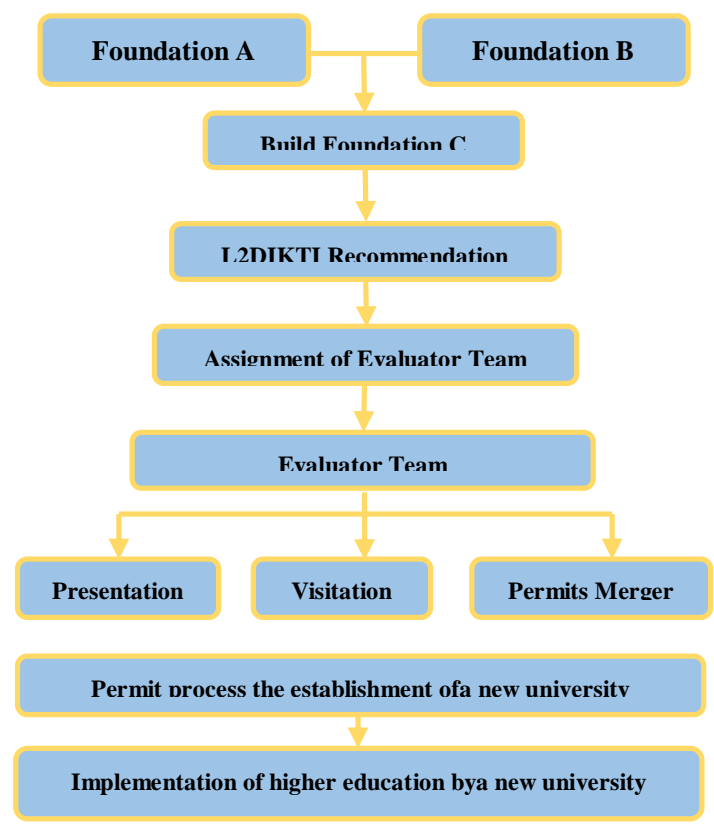

Figure 2. The second stage of merger procedures

Some examples of university mergers in Indonesia are: STIKES Ahmad Yani and STMIK Ahmad Yani Yogyakarta have merged into a new entity called Jenderal Ahmad Yani University in 2017.

\subsection{Acquisitions}

Acquisition of private university institutions is: (1) the acquisition of 1 (one) or more private universities managed by 1 (one) or more of one foundation into 1 (one) foundation, for illustration: private university institution A and private university institution B which foundation $A$ and foundation $B$ respectively manage are combined with established private university institutions $\mathrm{C}$ which are managed by foundation $\mathrm{C}$, then private university $\mathrm{X}$ and private university $\mathrm{Y}$ managed by $\mathrm{Z}$ foundations united with private universities D (existing) and managed by foundation D (existing); (2) the acquisition of 1 (one) private university is managed by the same base of multiple private universities. Example: the acquisition of a private university $\mathrm{A}$, a private university $\mathrm{B}$, and a private university $\mathrm{C}$ into private university $\mathrm{C}$ which is still managed by foundation $\mathrm{A}$.

There are many reasons why a foundation demands a license for 1 or more private universities, each managed by a different or the same foundation, among others: (1) private universities in many private universities have a shared vision, to speed up the achievement of a united vision of private university institutions through the acquisition by a base; (2) many private university institutions managed by the same or different foundations are no longer able to carry out their studies programs, both academically and nonacademically, but such capacity will grow and expand when the different private universities are unified within 1 (one) other foundation; (3) a foundation that manages many private university institutions brings together 1 (one) private university, to increase the consistency, productivity, and effectiveness of the management of multiple private university institutions;(4) a foundation which by incorporating non-STEM study programs (science, technology, engineering, and mathematics) wants to alter the form of 1 (one) private university, but which is required to be subject to a moratorium because the initiation of non-STEM study programs will take over other private universities which will be merged into private universities with a non-STEM study program; (5) private universities subject to provisions must regenerate the number and type of non-STEM study program but must be restricted because there is a current moratorium on the opening of non-STEM study programs, and they can take over the obligation of other private universities with non-STEM study courses which are complementary to private universities affected by the provisions.

The acquisition of oneor more of the private university institutions into 1 (one) the same or different foundations in another private university would be as follows: (1) if the acquisition of 1 (one) or more private universities by 1 (one) or more foundations in 1 (one) foundation run by 1 (one) private university administrators, foundations operating the private university institutions in management shall transfer, in the interest of the foundation, the ownership status of all properties (facility, facilities or other assets); (2) the accreditation status of study programs and university institutions may be permanent or change; (3) data and information in the Higher Education Database (PD DIKTI) must be changed from data and information on several private university institutions that unite into 1 (one) data and information from 1 (one) private university institution as a result of the acquisition.

Private university acquisition criteria shall be as follows: (1) foundations acquiring and managing private university institutions, or foundations acquiring under its management several private university institutions that meet the legality element; (2) study programs at private university institutions that will be combined only have study programs that have at least a minimum 
accredited status and rank; (3) each private university institution that will be acquired has reported the implementation of higher education to the Higher Education Database (PD DIKTI); (4) if the acquired private university institution requires the addition of a new study program, the curriculum for each study program that was recently opened in the acquired private university institution has been prepared based on the competence of graduates according to national higher education standards; (5) if the acquired private university institution requires the addition of a new study program, there will be at least 6 (six) lecturers for each study program in the Diploma Program or Undergraduate Program at the acquired private university institution, unless otherwise stipulated by laws and regulations, with the lowest qualification with a master's degree in the science and technology in accordance with the study program that will be opened in the acquired private university institution; (6) if a new private university institution requires the addition of a new study program, the lecturers in the study program that will be opened at the acquired private university institution will be at least 58 (fifty eight) years old at the time of being accepted as a lecturer, willing to work full time for 40 ( forty) hours per week, do not have a National Lecturer Identification Number (NIDN) or a Special Lecturer Identification Number (NIDK), or if you already have a NIDN/NIDK from another study program at the newly acquired private university, must maintain the lecturer ratio and students in abandoned study programs, not teachers who already have a serial Number of Educators and Education Personnel (NUPTK), not permanent employees of other agencies, and not state civil servants; (7) if a new private university institution requires the addition of a new study program, there will be at least 3 (three) staff of educational staff in the study program to be opened at the unified private university institution to serve each study program in the diploma program or undergraduate program, and 1 (one) person to serve the libraries of new private university institutions as a result of the acquisition, with the lowest qualification having a diploma three, with a maximum age of 56 (fifty six) years; and willing to work full time for 40 (forty) hours per week.

Requirements (1) and (5) are absolute conditions, meaning that the plan to acquire private university institutions will still be assessed but not further processed if these two requirements are not complied with.

Documents for proposals to acquire private university institutions consist of: (1) notaries for creating or amending each organizing body or fund that acquires and manages private university institutions; (2) decisions for legalizing all organizing structures referred to in the letters as legal entities from the competent authorities; (3) a letter dressed by an organizing band or a foundation acquiring the acquisition of a multiple private university institution, (4) the Decree of the
MoEC, MoNE, or MoTRHE on the authorization of each private university institution to create and the license to acquire (the private university institution); (5) land status certificates, to be issued on behalf of the acquisition agency and foundation or land rental arrangement between the acquiring organizing agency and the holder of land title status by December 21, 2035 , for prospective university private institutions to be acquired; (6) the BAN-PT accreditation instrument in the event of a change in the form of an acquired organization, a private university institution; (7) the acquisition of private university institutes includes the addition of new research programs, BAN-PT/LAM accreditation instruments that have been filled in by the foundation (one instrument for each study program); (8) financial reports for a period of 2 years the latter, either those who are going to acquire or being acquired, (9) recommendations from higher education service institutions (L2 DIKTI) in the areas of private university institutions resulting from the acquisition.

The example of university acquisitions in Indonesia is based on Letter 440/923.1/DINKES/2016 and Letter 5271/A.A3/PL/2016, The Bengkulu Provincial Government Health Polytechnic handed over its management to Bengkulu University.

\section{CONCLUSION}

In summary, clusterizations, mergers and acquisitions of higher education in Indonesia have advantages and disadvantages to the advancement of higher education. For the clusterizations policy, follow up recommendations that can be given are: (1)strengthened potential for international reputation building; (2) strengthening internal management ability to utilize higher education resources; (3) improvement of human resource efficiency and strengthened internal management capacity; (4) improved human resource quality and management framework and improved levels of input and process quality; (5) increased awareness of Tri Dharma accomplishments; (6) improved human resource quality and internal management; (7) enhanced levels of input and process standard; and (8) increased knowledge of Tri Dharma accomplishments.

To develop higher education skills and standards by merger and acquisition strategies, the recommendations include: (1) the government is required to take a strong stand in rationalizing the composition of lecturers and students; (2) promoting the accreditation of study programs, monitoring transfers of leadership; and (3) planning criteria for the management of facilities and infrastructure, respecting the rights and duties of lecturers and educational staff.

\section{REFERENCES}

[1] Kim, S., \& Lee, J.-H. Changing facets of korean higher education: market competition and the role 
of the state. High Educ 52, 557-587. https://doi.org/10.1007/s10734-005-1044-0, 2006.

[2] Kim, T. Higher education reforms in south korea:public-private problems in internationalising and incorporating universities. Policy Futures in Education Volume 6 Number 5 2008, 558-568. https://journals.sagepub.com/doi/pdf/10.2304/pfie. 2008.6.5.558.

[3] Sunder, S. Highereducation reforms in India. p. 2010, July 28. https://ssrn.com/abstract $=1652277$ or http://dx.doi.org/10.2139/ssrn.1652277.

[4] Indonesia, P. Laws of the republic Indonesia number 12 of 2012 about higher education. UU No. $\quad 12 \quad$ Tahun 2012. https://ldikti8.ristekdikti.go.id/wpcontent/uploads/2019/02/Undang_Undang_Nomor _12_Tahun_2012_Pendidikan_Tinggi.pdf.

[5] Waks, L. J. In the shadow of the ruins: globalization and the rise of corporate universities. Policy Futures in Education, Volume 2, Number 2, 278-298.
[6] Attamimi, A. N., Nirmala, I., \& Putri, D. A. Higher education statistical year book 2019. Jakarta: Pusat Data dan Informasi IPTEK DIKTI. http://pusdatin.ristekdikti.go.id.

[7] Serfiyani, C. Y. Restrukturisasi perguruan tinggi swasta sebagai upaya penyehatan dan peningkatan kualitas institusi. Ius Quia Iustum Law Journal of Islamic University of Indonesia , https://doi.org/10.20885/iustum.vol27.iss2.art10or https://journal.uii.ac.id/IUSTUM/article/view/1461 8/10411. 2020.

[8] Education, D. G. Klasifikasi dan pemeringkatan perguruan tinggi Indonesia. Jakarta. http://lldikti6.id/wpcontent/uploads/2020/09/KLASTERISASI-PT2020.pdf: Ministry of Education and Culture.

[9] Nirmala, I., \& Attamimi, A. N. Higher education statistical year book 2017. Jakarta: Pusat Data dan Informasi IPTEK http://pusdatin.ristekdikti.go.id. 